\title{
Development of alternative ship propulsion in terms of exhaust emissions
}

\author{
Jarosław Markowski ${ }^{1, a}$, Jacek Pielecha ${ }^{1}$, Remigiusz Jasiński ${ }^{1}$, Tomasz Kniaziewicz², Paweł Wirkowski ${ }^{2}$ \\ ${ }^{1}$ Poznań University of Technology, Institute of Combustion Engines and Transport, Poznań, Poland \\ ${ }^{2}$ Polish Naval Academy, Faculty of Mechanical and Electrical Engineering, Gdynia, Poland
}

\begin{abstract}
The introduction of new emission limits for exhaust emissions of ship engines contributes to the development of new powertrain solutions. New solutions in the simplest approach concern the reduction of the concentration of sulfur in motor fuels. Typically, the aforementioned fuels have a lower value of viscosity which causes a number of supply system problems. It is becoming more and more common to use fuel cells in engine rooms of various types of marine vessels. Unlike conventional systems that use internal combustion engines, these systems have zero exhaust emissions. Hydrogen, methanol, methane and other substances may be used as a fuel in fuel cells. However, so far the best operating parameters are manifested by cells powered by hydrogen, which is associated with difficulties in obtaining and storing this fuel. Therefore, the use of turbine engines allows the obtaining of large operating and environmental advantages. The paper presents a comparison of the ecological parameters of turbine and piston engines.
\end{abstract}

\section{Introduction}

The energy demand of the currently functioning civilization on Earth intensifies with the increasing population and social development (Fig. 1). This demand is generated by the industry mainly associated with the production of various goods and the service sector, among which a significant share of the energy consumption has to do with transportation.

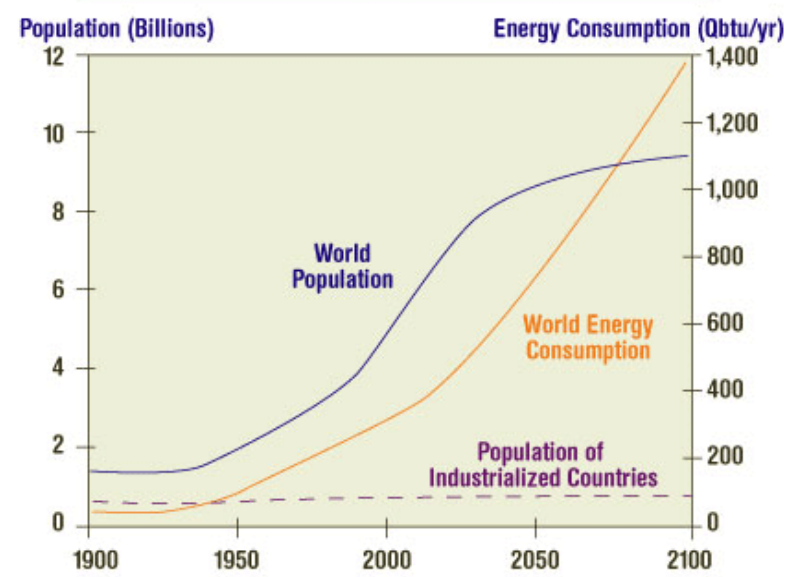

Figure 1. Projected number of people on Earth, and a forecast of energy consumption $[2,6,7]$.

The energy for the purpose of civilization is produced mostly from fossil fuels such as coal, oil, and natural gas. This group may also include nuclear energy as it uses the elements contained in uranium ores (Fig. 2). A small share of energy is derived from the wind or the Sun. Therefore, the production of energy by fuel oxidation is associated with the generation of $\mathrm{CO}_{2}$ and other harmful compounds.

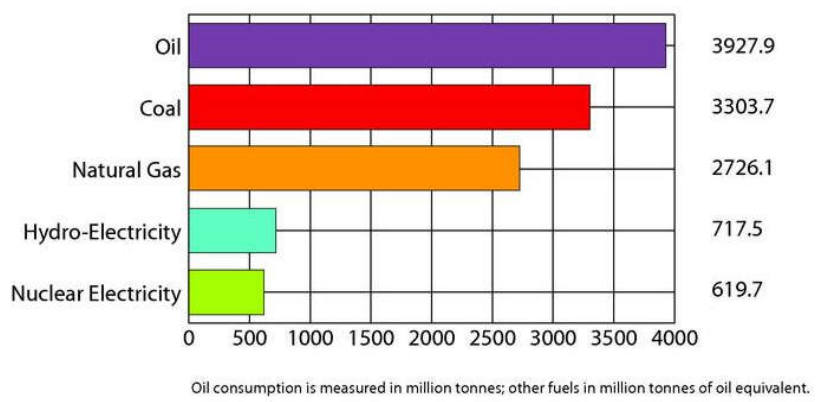

Figure 2. Oil consumption in million tons compared to other energy sources in reference to oil [2]

The emission of harmful compounds - $\mathrm{CO}, \mathrm{HC}, \mathrm{NO}_{\mathrm{x}}$ and $\mathrm{PM}$ - has a negative impact on the environment of human beings and is the cause of many diseases and the deterioration of health. In this respect, bearing in mind the growing energy needs of society, and at the same time improving the environmental conditions, it is important to reduce the negative effects of energy production by stimulating activities related to the development of energy systems such as internal combustion engines, exhaust aftertreatment systems, new fuels, fuel cells, diesel-electric and electric drive systems $[1,4,5]$. Activities in this field aim to reduce fuel consumption by increasing the efficiency of the powertrain. However, due to the increasing population and transportation needs these actions are still insufficient. The importance of transport in the social functioning of civilization is exemplified when we

a Corresponding author: jaroslaw.markowski@put.poznan.pl 
compare the daily consumption of fuels made from crude oil juxtaposed with respect to the type of the means of transport (Fig. 3).

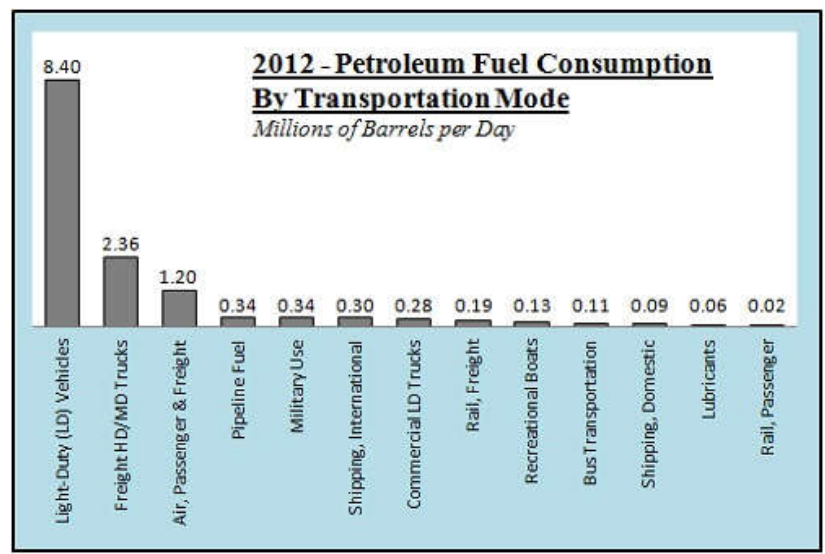

Figure 3. Daily consumption of petroleum fuels juxtaposed with the type of the means of transport [2].

In this comparison the transport by means of vessels consumes 0.39 million barrels per day, which per year gives about 140 million barrels of oil [2]. Therefore standardization procedures associated with the reduction of emissions from marine engines are being introduced.

New limits on exhaust emission from marine engines enforce the use of exhaust aftertreatment systems and the pursuit of new solutions associated with the powertrains of vessels. New solutions are focused on the use of sulfur-free fuels, light diesel oil, fuel biocomponent additives and other alternative fuels. These fuels are more expensive, which results in the deterioration of the economic aspects of maritime transport. Therefore, the use of desulphurised fuels is treated as a temporary solution. The attention of ship owners and designers who develop new constructions is focused on the pursuit of other sources of energy to meet the functional needs of the ships and their drives. In the area of interest there are engine rooms with four-stroke engines in combination with electricity generators powered by light fuels and equipped with exhaust gas cleaning systems. The energy that is generated is used for the functional needs and to power electric engines of the main drive.

The use of Diesel engines equipped with exhaust gas cleaning systems is expensive and requires considerable space of the engine room. Therefore, more and more opportunities are created to explore various other solutions which are already used in vehicles such as fuel cell systems and turboshaft engines for marine applications. The use of fuel cells as propulsion is limited by the issue of efficiency combined with the volume of the engine room which the system of fuel cell requires. The relationship between these parameters depends on the type of fuel cell supply. Hydrogen, methanol, methane and others may be used as a fuel in fuel cells. However, so far the best operating parameters are manifested by cells powered by hydrogen, which is associated with difficulties in the obtaining and storing of this fuel. The solution of this problem may lie in the synthesis of methanol or ethanol reactors included in the propulsion system of the vessel, whose task is to make the hydrogen power the cell. The advantage of these systems, in contrast to conventional systems that require internal combustion engines, also has to do with low exhaust emissions, which is often associated with the emission of water or water and carbon dioxide in the case of the use of methane, methanol or ethanol as a fuel $[3,5]$.

In the case of turbine engines a disadvantage has to do with a lower efficiency of generating energy which is evidenced by the high value of the specific fuel consumption (Fig. 4). The most important factor is the concentration of power generated by the engine in relation to the turbine system weight and its volume in the engine room. The advantage of this solution has to do with the possibility to use light fuels, sulfur-free, alternative fuels such as vegetable oil esters, methanol, ethanol, methane and gaseous fuels as natural gas and propane-butane.

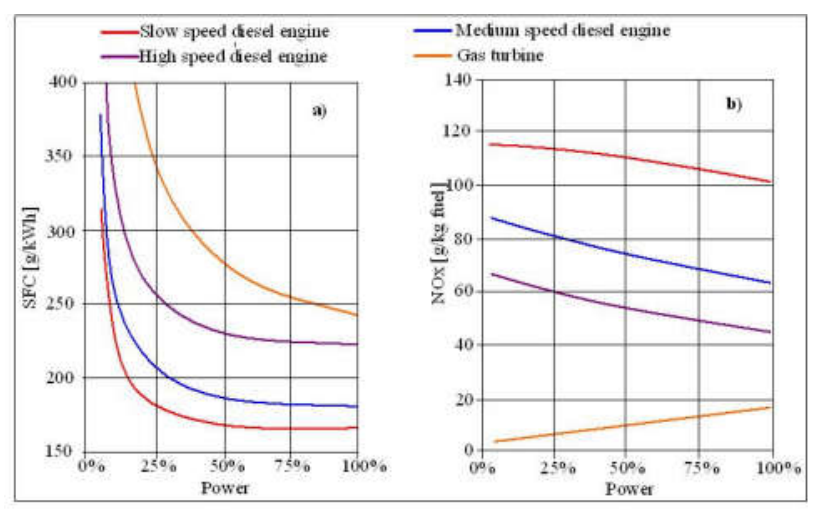

Figure 4. Specific fuel consumption and $\mathrm{NO}_{\mathrm{x}}$ emissions as a function of the power of Diesel and turbine engine for marine applications [2].

The use of natural gas as a fuel for power systems and propulsion in particular may be advantageous in the case of gas tankers transporting this type of fuel. The argument for the use of systems of turbine generators of electricity is the possibility to increase the cargo space (Fig. 5), which improves transport economics and compensates for the drawback resulting from the low level of turbine engine efficiency.
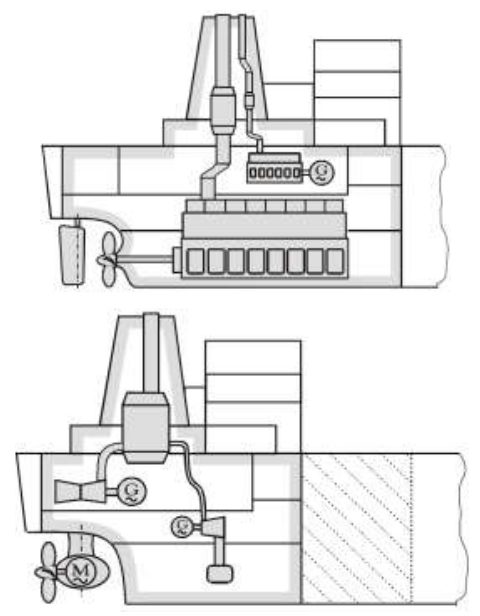

Figure 5. Comparison of the drive system of the turbine generators of energy for the proposed LNG tanker to the traditional direct drive with a low-speed Diesel engine. 
Issues related to the assessment of the propulsion systems of vessels is multifaceted and the restrictions that were introduced in the form of standards and emission limits lead to an assessment of the ecological properties of these types of propulsion. The article presents an overview of the results of research in the environmental performance of the medium speed piston engine and the turbine engine with a power takeoff shaft of ships. The parameters which enabled a mutual comparison of the ecological properties of these engines constitute the values of exhaust emissions of individual compounds.

\section{Research of environmental parameters of the 6AL20/24 marine engine}

Research of environmental parameters of piston marine engine was carried out on the 6AL20/24 engine (Fig. 6). This is a medium speed, four-stroke inline engine, with six pistons of $200 \mathrm{~mm}$ diameter and a stroke of $240 \mathrm{~mm}$, compression ignition, powered by lightweight fuel, supercharged, designed for marine applications. The rated output power is $397 \mathrm{~kW}$ at $720 \mathrm{rev} / \mathrm{min}$ of the crankshaft. The engine was produced under SULZER license by H. Cegielski Poznań. This engine can be applied as the main drive of small vessels or can be used in the systems of generators.

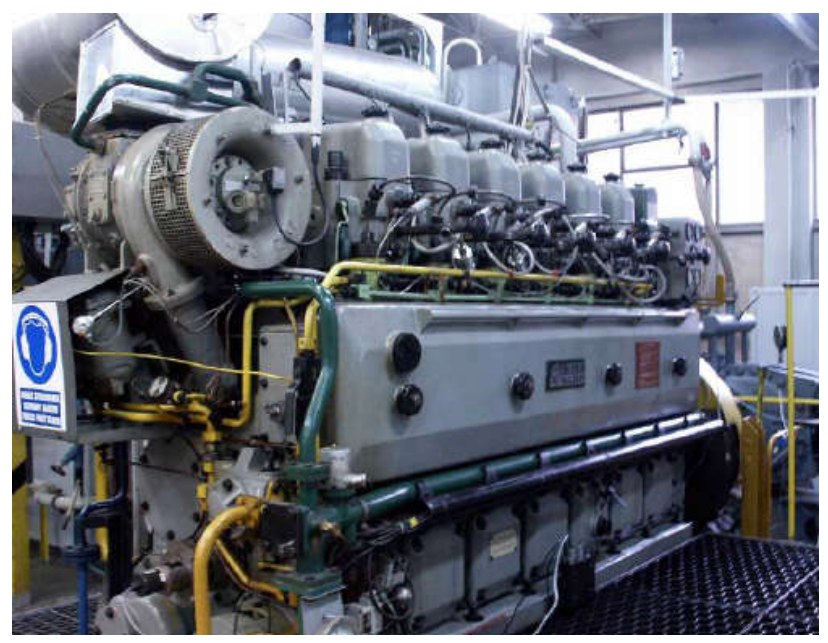

Figure 6. View of the 6AL20/24 engine.

During the test the engine was loaded according to its characteristics by means of a water brake, whereas the measurement of the concentration of various toxic compounds contained in the exhaust gas was carried out by means of a HORIBA MEXA 9000 gas analyzer. The analyzer enables the continuous monitoring of toxic compounds in exhaust gases. It allows the measurement of CO - using the Non-Dispersive InfraRed (NDIR); HC - using a Flame Ionisation Detector (FID) and $\mathrm{NO}_{\mathrm{x}}-$ by means of the chemiluminescence method (CLD) with a $\mathrm{NO}_{2} / \mathrm{NO}$ converter. Additionally, it provides an analysis of the oxygen content in the exhaust gas using a paramagnetic analyzer (PMD). In accordance with the requirements of ISO 8178 for heavy-duty Diesel engines (HD-D), the process of gas sampling required the use of a heated gas line (with a heated filter and pump) - with a temperature of $190^{\circ} \mathrm{C}$ for the purpose of the measurement and analysis of HC (H-FID) and $110^{\circ} \mathrm{C}$ for the analysis of $\mathrm{NO}_{\mathrm{x}}$ (H-CLD). The results are shown in Table 1.

Table 1. Measurement results of the concentration of $\mathrm{CO}, \mathrm{HC}$, $\mathrm{NO}_{\mathrm{x}}$ and specific emission values for the selected engine load levels of the 6 AL20/24 engine

\begin{tabular}{|c|c|c|c|c|}
\hline \multicolumn{2}{|c|}{$\mathbf{N}_{\mathrm{e}} / \mathbf{N}_{\mathrm{e} \max }[\%]$} & 13 & 66 & 84 \\
\hline \multicolumn{2}{|c|}{ Power [kW] } & 55 & 277 & 356 \\
\hline \multirow{3}{*}{ Concentration } & $\mathrm{CO}[\mathrm{ppm}]$ & 600 & 450 & 410 \\
\hline & $\mathrm{HC}[\mathrm{ppm}]$ & 50 & 51 & 48 \\
\hline & $\mathrm{NO}_{\mathrm{x}}[\mathrm{ppm}]$ & 1100 & 1070 & 1050 \\
\hline \multirow{3}{*}{$\begin{array}{c}\text { Specific } \\
\text { emissions }\end{array}$} & $\mathrm{CO}[\mathrm{g} / \mathrm{kWh}]$ & 4.0 & 2.6 & 2,4 \\
\hline & $\mathrm{HC}[\mathrm{g} / \mathrm{kWh}]$ & 0,2 & 0,15 & 0,14 \\
\hline & $\mathrm{NO}_{\mathrm{x}}[\mathrm{g} / \mathrm{kWh}]$ & 14 & 11 & 10 \\
\hline
\end{tabular}

\section{Research of environmental parameters of turbine engine GTD-350}

Research of environmental parameters of the turbine engine was carried out by means of the GTD-350 engine (Fig. 7); the rated power is $298 \mathrm{~kW}$. The GTD-350 engine was designed as an aviation engine intended for the Mi-2. It is fitted with two impellers and a separate power turbine. An overview of its key components and its working principle are presented in Fig. 8. Air is supplied to the GTD-350 via a compressor with seven axial stages and one centrifugal stage, and is subsequently fed into a can combustor. Fuel is delivered to the chamber by an injector valve. Fuel combustion generates a growth in the thermodynamic parameters of the working medium, which - once directed to the high stage turbine - drives the compressor.

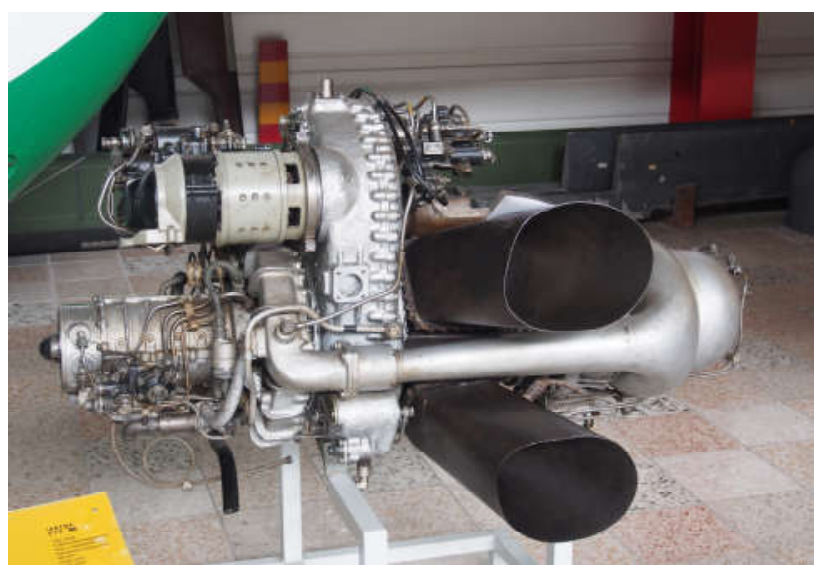

Figure 7. GTD-350 engine overview.

Subsequently, the working medium is directed to the power turbine that drives the propeller shaft via transmission gear. Such a design is characteristic for the placement of the combustion chamber downstream of the turbines. As a result, it is possible to use shorter impeller shafts and thus high 
engine speeds may be reached. Such a solution had one more significant advantage: reduced engine mass and improved an economic performance. The propulsion system of the Mi-2 consists of two GTD-350s that propel the final drive, and - indirectly - the main and auxiliary rotor and other units coupled with the transmission.

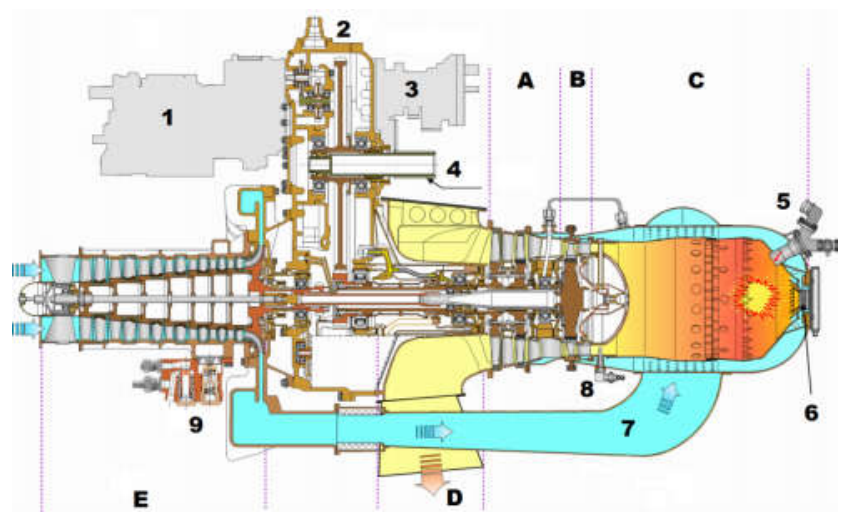

Figure 8. GTD-350 engine overview [4]: A - power turbine, B - compressor turbine, $\mathrm{C}$ - combustion chamber, D - exhaust gas outlet, E - compressor, 1 - regulator pump, 2 - gearbox, 3 power turbine speed governor, 4 - power take-off, 5 - igniter plug, 6 - injector valve, 7 - air tube, 8 - thermocouple, $9-$ wastegate.

Characteristics of the GTD-350 engine:

- Power: $298 \mathrm{~kW}$,

- Instantaneous fuel consumption: $0.475 \mathrm{~kg} / \mathrm{kWh}$,

- Air flow rate: $2.2 \mathrm{~kg} / \mathrm{s}$,

- Compression ratio: 6.05,

- Engine weight $135 \mathrm{~kg}$.

The emission of toxic compounds was determined on the basis of the concentration of carbon monoxide, hydrocarbon, nitrogen oxide and carbon dioxide, measured with a Semtech-DS (Fig. 9), a portable exhaust gas analyzer by Sensors.

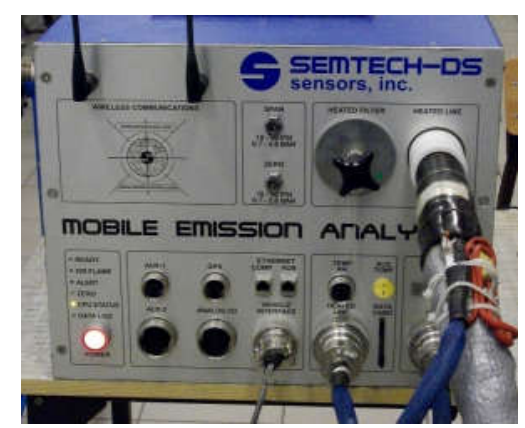

Figure 9. View of the Semtech-DS analyzer.

The results of the concentration of toxic compounds in exhaust gases are presented as measured values of carbon monoxide, hydrocarbons, nitrogen oxides and carbon dioxide recorded over several minutes of measurement (Fig. 10). Measurements were carried out for all selected helicopters during their respective preflight tests. Individual tests may differ in terms of duration from the accepted procedure presented in the guidelines applicable to a given helicopter type. However, engine loads during the tests were strictly respected at all times.
Measurements of the concentration of harmful exhaust compounds, $\lambda$ ratio air-fuel equivalence and fuel consumption during engine operation, made it possible to assign the engine load values to individual states of the engine operation during the test. The emission intensity of the individual compounds was determined by assigning the measured concentration of the individual compounds in the exhaust gas to the appropriate states of engine load and by determining the mass of exhaust gas.

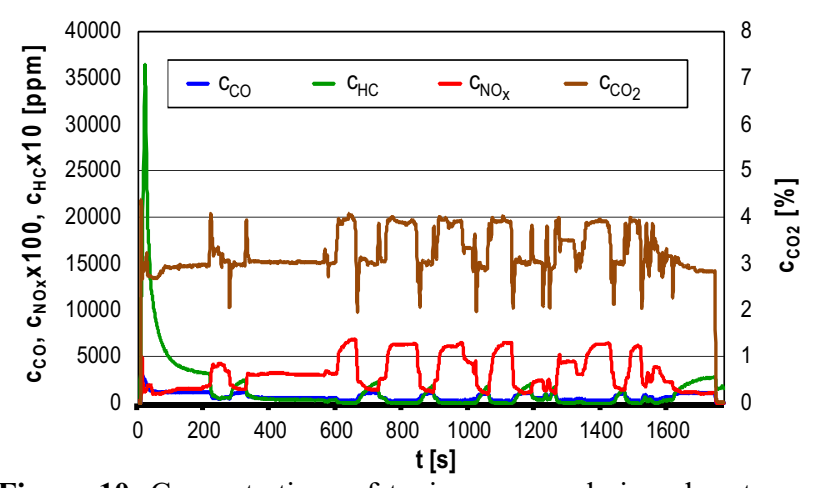

Figure 10. Concentrations of toxic compounds in exhaust gas from the GTD-350 engine.

The value of the specific emissions of harmful compounds contained in exhaust gases was determined by referring the emission intensity to the power generated by the engine at a given engine load (Table 2).

Table 2. Measurement results of the concentration of $\mathrm{CO}_{2}, \mathrm{CO}$, $\mathrm{HC}, \mathrm{NO}_{\mathrm{x}}$, the intensity of emissions and specific emissions values for the selected GTD-350 engine load.

\begin{tabular}{|c|c|c|c|c|}
\hline \multicolumn{2}{|c|}{$\mathbf{N}_{\mathrm{e}} / \mathbf{N}_{\mathrm{e} \max }[\%]$} & 15 & 65 & 95 \\
\hline \multicolumn{2}{|c|}{ Power $[\mathrm{kW}]$} & 45 & 194 & 283 \\
\hline \multirow{4}{*}{ Concentration } & $\mathrm{CO}_{2}[\%]$ & 2.8 & 3.0 & 3.9 \\
\hline & $\mathrm{CO}[\mathrm{ppm}]$ & 1100 & 700 & 200 \\
\hline & $\mathrm{HC}[\mathrm{ppm}]$ & 250 & 50 & 5 \\
\hline & $\mathrm{NO}_{\mathrm{x}}[\mathrm{ppm}]$ & 15 & 32 & 60 \\
\hline \multirow{4}{*}{$\begin{array}{l}\text { Emission } \\
\text { intensity }\end{array}$} & $\mathrm{CO}_{2}[\mathrm{~g} / \mathrm{s}]$ & 61.16 & 74.38 & 87.65 \\
\hline & $\mathrm{CO}[\mathrm{g} / \mathrm{s}]$ & 2.72 & 0.782 & 0.582 \\
\hline & $\mathrm{HC}[\mathrm{g} / \mathrm{s}]$ & 1.11 & 0.436 & 0.075 \\
\hline & $\mathrm{NO}_{\mathrm{x}}[\mathrm{g} / \mathrm{s}]$ & 0.0404 & 0.0962 & 0.1425 \\
\hline \multirow{4}{*}{$\begin{array}{c}\text { Specific } \\
\text { emissions }\end{array}$} & $\mathrm{CO}_{2}[\mathrm{~g} / \mathrm{kWh}]$ & 4926 & 1382 & 1115 \\
\hline & $\mathrm{CO}[\mathrm{g} / \mathrm{kWh}]$ & 219.1 & 14.53 & 7.40 \\
\hline & $\mathrm{HC}[\mathrm{g} / \mathrm{kWh}]$ & 89.4 & 8.10 & 0.95 \\
\hline & $\begin{array}{c}\mathrm{NO}_{\mathrm{x}} \\
{[\mathrm{g} / \mathrm{kWh}]}\end{array}$ & 3.25 & 1.79 & 1.81 \\
\hline
\end{tabular}




\section{Comparative analysis of the environmental performance of the 6AL20/24 engine and the GTD-350 engine}

The results of the study of the concentration of harmful compounds in the exhaust allow the assessment of the mass content of the compound in the exhaust gas. The engine load is very important. Although the engines that are compared are characterized by very similar values of power, the comparison must be done for the relative values of the engine load. If we compare the results that were obtained (Fig. 11 and Fig. 12), we may conclude that the concentration of carbon monoxide in the exhaust gas of the 6AL 20/24 engine is two times lower than in the exhaust gas from the GTD-350engine. The values of the concentration of hydrocarbons in the exhaust gas of the two engines are similar, while the concentration of nitrogen oxides is about sixteen times larger in the exhaust gas of the 6AL 20/24 engine.

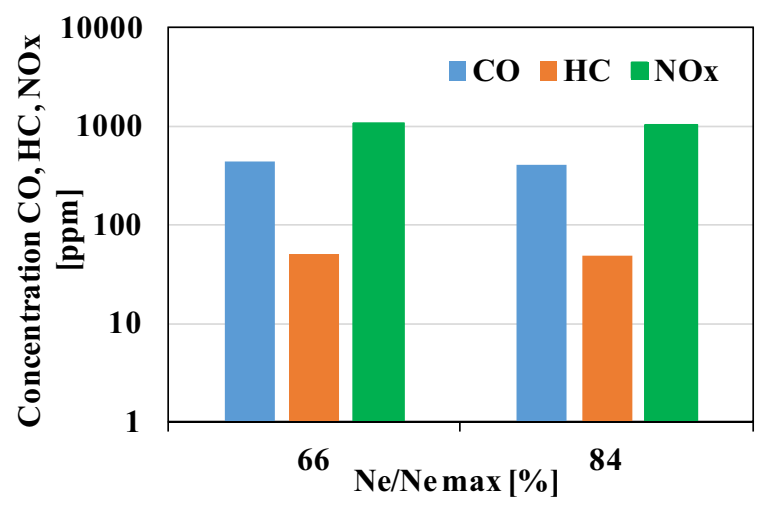

Figure 11. Concentrations of harmful compounds in the exhaust of the 6AL20/24 engine as a function of the engine load.

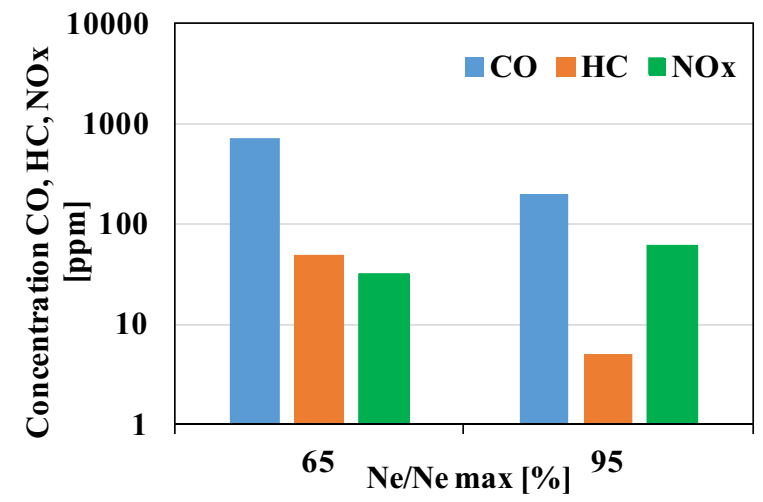

Figure 12. Concentrations of harmful compounds in the exhaust of the GTD-350 engine as a function of the engine load.

Assessment of compound concentration in the exhaust gas is not sufficient to determine the emissions of these compounds to the environment. What is necessary in this regard is the knowledge of the exhaust gas mass flow which together with the power value obtained by the engine at a given operating point allows us to evaluate the specific emissions of the individual compound. The values of the specific emissions are closely dependent on the engine load, therefore there is a necessity to compare the values obtained for similar load conditions of the engine. The obtained values of specific emissions of each of the compounds for the engines that were tested are shown in Figure 13 and 14. The specific emissions values of the engines that were comparerd are connected with the operating points of the engine with the highest time density. The relative values of the engines load are similar. When we analyze the specific emissions associated with the application of $65 \%$ of the maximum load of the GDT-350 turbine engine we may determine that this influences the following: 5-times greater specific emission of carbon monoxide, about 50-times greater specific emission of hydrocarbons and about 6-times lesser specific emission of carbon oxides.

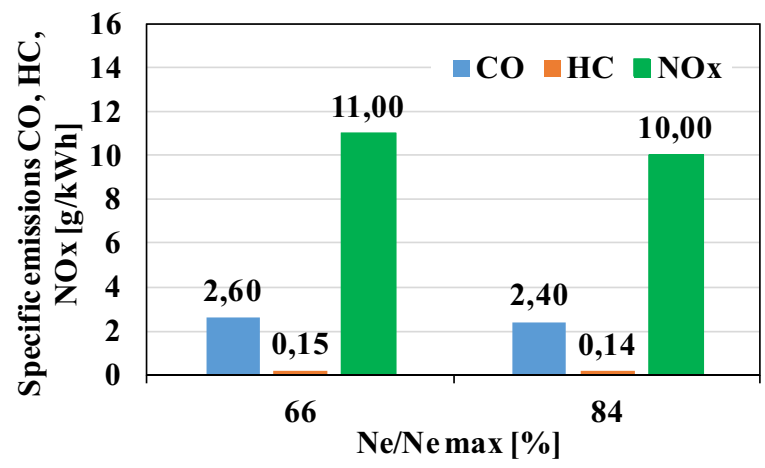

Figure 13. Specific emissions of harmful compounds in the exhaust of the 6AL20/24 engine as a function of the engine load.

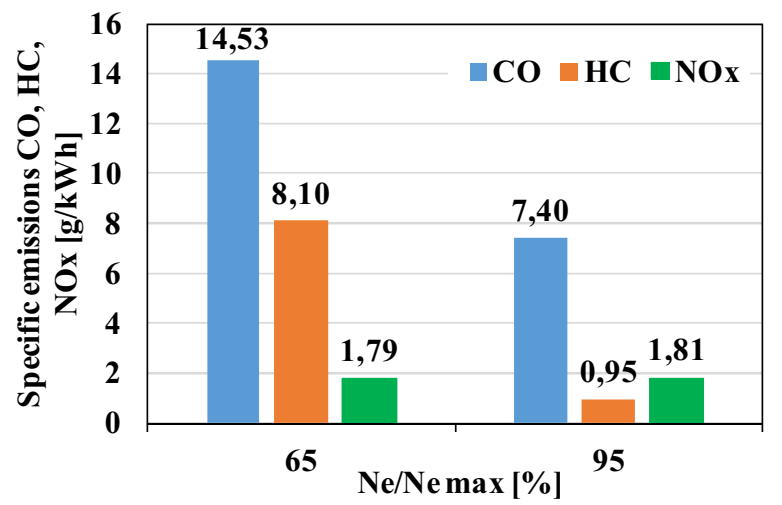

Figure 14. Specific emissions of harmful compounds in the exhaust of the engine GTD-350 as a function of engine load.

For comparison's sake, the values of specific emissions obtained at higher values of engine load $-84 \%$ and $95 \%$ - engine GTD-350 are characterized by about three times larger specific emissions of carbon monoxide, about six times larger specific emissions of hydrocarbons, and about five times lower specific emissions of nitrogen oxides.

\section{Summary}

We carried out a comparative analysis of the ecological properties of a piston engine with compression ignition intended for ship propulsion and the turboshaft engine, which consists in a comparison of the concentration of toxic compounds contained in exhaust gases and 
specific emissions of these compounds, indicates the environmental benefits of piston engines application. It is justified by the low values of specific emissions of pollutants. In particular, it concerns the carbon monoxide and hydrocarbon emissions. The obtained values of the specific emissions indicate a high value of piston engine efficiency, which in the case of application in the turbine engine can be a very serious problem. The argument of the concentration of power and a smaller volume of engine room translates into a necessity of larger fuel tanks. For this reason, the cargo space of the ship cannot be increased.

Accordingly, the use of turbine engines in vessels cannot be evaluated positively. Therefore, it is necessary to pursue other ways of obtaining high-efficiency propulsion.

\section{References}

1. M. Dudek, P. Tomczyk, P. Wygonik, M. Korkosz, P. Bogusz, B. Lis, Hybrid fuel cell-battery system as a main power unit for small unmanned aerial vehicles (UAV). International Journal of Electrochemical Science, Vol. 8, 2013.

2. I. Komar, B. Lalić, Sea Transport Air Pollution (Chapter 8 in: Current Air Quality Issues. Edited by F. Nejadkoorki, ISBN 978-953-51-2180-0,) (2015)

3. W. C. Lewandowski, Proekologiczne odnawialne źródła energii, WNT Warszawa. 2012.

4. J. Merkisz, J. Markowski, J. Pielecha, Selected issues in exhaust emissions from aviation engines. Nova Science Publishers, New York 2014.

5. J. Merkisz, I. Pielecha, Alternatywne napędy pojazdów, Wydaw. Politechniki Poznańskiej, 2006.

6. Energy Projections: "Global Energy Perspectives" ITASA / WEC

7. Population Projections: United Nations "Long Range World Population Projections: Based on the 1998 Revision" 